\title{
Tigrinya Language
}

National Cancer Institute

\section{Source}

National Cancer Institute. Tigrinya Language. NCI Thesaurus. Code C154167.

An Afroasiatic language of the Semitic branch mainly spoken by the Tigrayan people in the highlands of Eritrea and in the Tigray Region of northern Ethiopia. 